NORDISK MUSEOLOGI $1994 \cdot 2$, S. 47-56

\title{
DEN NATURHISTORISKE SAMLING OG FORSKNINGEN
}

\author{
Niels P. Kristensen
}

Blandt de naturhistoriske forskningsomrader, som er helt afhangige af samlinger, har den biologiske systematik fäet en serlig aktualitet gennem opmerksombeden om 'biodiversitetskrisen'. Systematikerne har berettigede ønsker om forøgede andele af de samlede biologiske forskningsressourcer, men det må samtidig erkendes, at den internationale naturhistoriske museumsverden ikke er optimalt struktureret: Krafterne er spredt for meget. En rekke aktuelle og forudseelige fornyelser i museernes arbejdsprocedurer opridses.

Vigtige områder inden for naturhistorisk forskning er helt afhængige af tilstedeværelsen af samlinger af konserverede naturgenstande. Det ligger i sagens natur, at denne forskning primært bliver de naturhistoriske museers anliggende.

Centralt inden for den samlingsafhængige naturforskning står den biologiske systematik, og nærværende indlæg vil være koncentreret om denne disciplin. Men selvfølgelig forudsætterer også mineralogisk og petrologisk forskning adgang til samlinger af mineraler og bjergarter, ligesom fossilsamlinger er grundlaget for studiet af flere andre facetter af palæontologien end de rent systematiske - herunder hele grænsefladen mellem (kvartær)palæontologi og arkæologi. Blandt 'neo'-biologer kan ikke blot systematikerne, men også populationsbiologer og funktionsanatomer hente studiemateriale $\mathrm{i}$ museernes samlinger. Og for miljøforskningen spiller samlingerne den vigtige rolle, at de $\mathrm{i}$ et vist omfang kan dokumentere 'tilstande, der var' - som et uvurderligt grundlag for bedømmelse af 'tilstande, der er'.

Når det imidlertid i 1990erne forekommer berettiget primært at fokusere på museernes rolle for den systematisk-biologiske forskning, så hænger det sammen med den stærkt forøgede opmærksomhed, som denne forskning har fået $\mathrm{i}$ forbindelse med debatten om biodiversitet, det levendes mangfoldighed. Kernen i denne debat er: At antallet af levende organismer er betydelig større end de fleste biologer forestillede sig for et par årtier siden, at denne formrigdom endnu i stort omfang er ukendt, og at ændringerne i naturlige økosystemer p.g.a de menneskelige samfunds vækst tilsyneladende uvægerligt må medføre udslettelse af talrige arter, før vi får erkendt deres eksistens og lært det mest elementære om dem.

Den museumsbaserede systematisk-biologiske forskning arbejder således $\mathrm{i}$ et 
48 kapløb med tiden. Det er denne forsknings ene hovedopgave at beskrive/navngive de levende organismer og lære deres geografiske udbredelse og væsentlige egenskaber at kende, samt at tilvejebringe værktøj til identifikationen af de kendte former (bestemmelseslitteratur). Den anden hovedopgave er at klassificere organismerne i overenstemmelse med deres afstamningshistoriske (fylogenetiske) slægtskab. Det er i kraft af en sådan klassifikation, at al biologisk information om de enkelte arter kan bringes til at danne et sammenhængende mønster.

Men den systematisk-biologiske forskning befinder sig ikke bare $i$ et kapløb med tiden. Den befinder sig selvfølgelig også $\mathrm{i}$ et kapløb med andre naturvidenskabelige - herunder andre biologiske - discipliner, når det gælder om at erhverve andele af de stillinger og driftsmidler, der nationalt $\mathrm{og}$ internationalt stilles til rådighed. De naturhistoriske museers chancer for at hævde sig i denne konkurrence vil i betydelig grad afhænge af deres evne til at producere forskningsresultater, som i brede kredse af det øvrige biologiske forskersamfund opfattes som relevante også for de problemstillinger, man her beskæftiger sig med.

\section{OPGAVERNES DIMENSIONER OG DEN NATURHISTORISKE MUSEUMS- VERDENS STRUKTUR}

Hvad er størrelsesordenen af de opgaver, den biologiske systematik står over for? Der findes ikke nogen samlet opgørelse over de beskrevne organismer - hvilket jævnligt overrasker ikke-biologer at høre men et kvalificeret skøn ${ }^{1}$ ligger på omkring 1,7 millioner navngivne nulevende arter. Mere end halvdelen udgøres af insekter (billerne alene er næsten 25\%!). Planterne (i den moderne afgrænsning, d.v.s. omfattende blomsterplanter, bregner, mosser m.v., men ikke svampe og 'alger') har andenpladsen med knap 15\%, og så er der igen et spring ned til spindlerne (mider, ederkopper m.v.), de 'ikkedyriske' svampe og bløddyrene, som hver tegner sig for lidt over $4 \%$. Alle andre organismegrupper rummer mindre end $3 \%$ hver.

Så mange - omtrent - har vi altså fået beskrevet og navngivet. Men det er kun for en lille brøkdels vedkommende, at de eksisterende beskrivelser er så gode, og samlede i så rationelt anlagte bestemmelsesværker, at en sikker artsbestemmelse nogenlunde let og hurtigt kan foretages; tilsvarende gælder det kun for en lille brøkdel, at vi har et rimeligt kendskab til den geografiske udbredelse, livscyklus og levevis. De bedst kendte former er, som man vel ville forvente, hvirveldyrene (ca $2,7 \%$ af de beskrevne organismer) og blomsterplanterne, men selv for disses vedkommende er den fylogenetiske klassifikation fremdeles meget ufuldstændig.

Når vi kun med grov tilnærmelse kan angive tallet på de allerede beskrevne organismer, så er det klart, at et skøn over antallet af de faktisk eksisterende nulevende arter må være behæftet med endda meget stor usikkerhed. En nøgtern nylig vurdering $^{1}$ når et tal på ca 12,5 millioner arter, altså en mere-end-7-dobling af det nu beskrevne artstal. I dette scenarie har insekterne øget deres andel (til næsten to trediedele), og det samme gælder de ikkedyriske svampe (nu ca 8\%), bakterier/ virus (nu tilsammen over $7 \%$ ), spindlerne $(6 \%)$ samt rundormene (4\%). Tilsvarende 

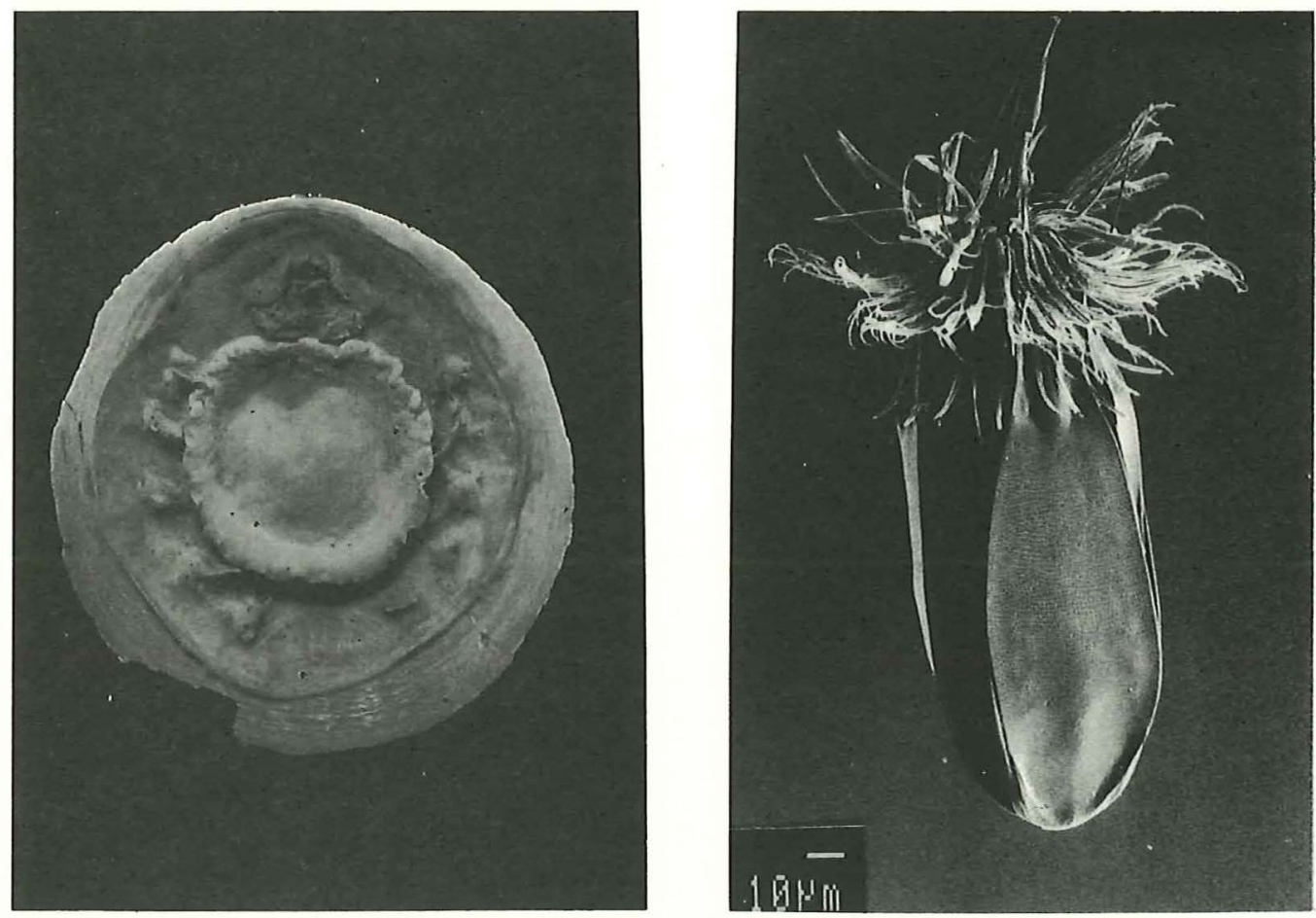

Systematiske biologer beskriver og navngiver årligt tusindvis af 'nye' (dvs. tidligere ubeskrevne) organismer. Langt de fleste kan betragtes som variationer over velkendte temaer. Men nu og da findes stadigvek former, som representerer helt andre organisationstyper end de hidtil kendte - $i$ hvert fald blandt nulevende organismer. Et par af efterkrigstidens mest bemarkelsesvardige opdagelser af nye hvirvellose dyr er gjort af danske zoologer, og det originale materiale ('typeserien') af disse former findes på Zoologisk Museum i Kobenhavn.

Fig. 1 (t.v.) viser 'urbloddyret' Neopilina galatheae Lemche, 1957, som blev indsamlet af Galatheaekspeditionen $i$ Stillehavet $i$ 1952. Modsat andre bloddyr har Neopilina $i$ sin bygningsplan tydelige spor af en 'leddeling' (en rytmisk gentagelse af organsystemer), hvilket allerede udefra kan erkendes gennem serien af parrede geller (de duskformede dannelser). Lignende former var i forvejen kendt som fossiler, men man troede tidligere, at de var uddode allerede $i$ devon-tiden. Munden, flankeret af hudfolder, ses foroven. Dyrets lengde er $3,3 \mathrm{~cm}$. Foto: G. Brovad.

Fig. 2 (t.h.) viser Nanaloricus mysticus Kristensen, 1983, den forst kendte reprasentant for rakken Loricifera, 'korsetdyr', som er den senest opdagede af dyrerigets 31 rekker. Reinhardt $M$. Kristensen, som beskrev rekken, fandt dyret under sit arbejde med andre dyregrupper tilhorende den marine 'meiofauna'-faunaen i hulrummene mellem sedimentpartikler i havbunden; denne fauna har vist sig at vere rig pa meget interessante, tidligere ukendte dyreformer. Alle meiofauna-dyr er selvfolgelig ganske små, målestokken t.v. er $10 \mu \mathrm{m}(11100 \mathrm{~mm})$. Munden findes foroven, på en udkrengelig 'mundkegle'. Scanning-elektronmikroskopisk foto: $R$. M. Kristensen. 
NiEls P. KRISTENSEN

50 er selvfølgelig andelen for blomsterplanters og hvirveldyrs vedkommende faldet drastisk, fordi der her kun ventes meget beskedne forøgelser af de kendte artstal.

Der er altså meget langt igen, før vi blot har beskrevet/navngivet de levende væsner, med hvilke vi deler denne planet. Og selvfølgelig endnu meget længere før vi ved blot det mest elementære om deres udbredelse og levevis og har placeret dem i det fylogenetiske system.

Det er på baggrund af denne situation, at systematiske biologer nu taler med store bogstaver om behovet for flere ressourcer. At de systematiske disicpliner i de seneste årtier har haft en vigende position inden for den samlede biologi er både forståeligt og berettiget $\mathrm{i}$ lyset af den eksplosive udvikling af bl. a. molekylærbiologi, eksperimentel fysiologi og økologi. Imidlertid synes der inden for det biologiske forskersamfund at være en udbredt erkendelse af, at den både relative og absolutte beskæring af de systematiske discipliner har medført reelle problemer, og at udviklingen må vendes. Den meget skæve aldersfordeling blandt aktive systematiske biologer ${ }^{2}$ viser således klart behovet for en styrkelse af de systematiske discipliner i biologistudierne på i hvert fald nogle universiteter og tillige behovet for flere rekrutterings/uddannelses-stillinger i systemet.

Men har de systematisk-biologiske discipliner berettigede krav om forøgede bevillingsandele, så må de jo til gengæld mødes af lige så berettigede krav om optimering af udnyttelsen af de allerede forhåndenværende midler. $\mathrm{Og}$ her melder problemerne sig. Efter min bedste overbevisning er den internationale naturhistoriske museumsverden ikke særlig hensigtsmæssigt struk- tureret, og hovedproblemet er, at ressourcerne er for spredte. Fokuserer man på den museale formidlingsfunktion, så er der naturligvis gode argumenter for, at der skal eksistere mange naturhistoriske museer, og de skal have en jævn geografisk spredning. Men der er ikke gode argumenter for en tilsvarende spredning af forskningsfunktionerne. Jeg mener med eftertryk, at slagordet small is beautiful IKKE har gyldighed for forskningsafdelingerne på de naturhistoriske museer, der har som væsentlig opgave at deltage i den internationale bestræbelse på at skabe overblik over den globale biodiversitet. Det enkelte museum skal have en stabsstørrelse, som muliggør en egentlig specialistdækning af de organismegrupper, museet beskæftiger sig med - og en rimelig teknikerstab til samlingsforvaltningen og til forskningsassistance. Museet skal have bred geografisk dxkning i samlingerne, fordi en tilfredsstillende behandling af en organismegruppes systematik forudsætter, at gruppens globale diversitet kan studeres; og nok er vi altid afhængige af lån fra andre museer, men en 'startkapital' af eget materiale er unægtelig meget værdifuld, hver gang et nyt forskningsprojekt påbegyndes. Og endelig skal museet have en instrumentering, som muliggør, at tidssvarende undersøgelser (f.eks. scanningelektronmikroskopi) kan udføres rutinemæssigt. Til et forskningsmuseums 'instrumentering' i bredere forstand hører også et omfattende bibliotek: Bl. a. på grund af originalbeskrivelsernes rolle for tolkningen af de gamle forfatteres videnskabelige navngivning af organismer er biblioteksværktøjet mere kritisk for den systematiske biologi end for nogen anden biologisk disciplin. 
De naturhistoriske museer (som National Museum of Natural History, Washington DC og The Natural History Museum, London), der er bedst forsynet med alle disse ressourcer, har i høj grad fungeret som 'lokomotiver' i den internationale systematisk-biologiske forskning, men vi kunne bruge væsentlig mere trækkraft af samme slags. Desværre når størsteparten af verdens naturhistoriske forskningsmuseer i flere ovennævnte henseender knap op på 'den kritiske masse', hvad der i mange tilfælde skyldes en forfejlet koordinering på nationale niveauer. Problemet illustreres tydeligt, når man sammenligner den engelske indflydelse på biodiversitetsforskningen med indflydelsen fra et så ressoucerigt land som Tyskland, der aldrig har haft noget naturhistorisk nationalmuseum, men en hel række mellemstore museer, som hver for sig har været markant underforsynet med personale- og/eller driftsmidler. Når dansk systematisk zoologi har haft den internationale gennemslagskraft, som vi nøgternt må registrere, så skyldes det netop i høj grad, at vor nationale indsats på dette felt i alt væsentligt har været samlet et enkelt sted: Københavns Universitets Zoologiske Museum, som faktisk både m.h.t. stab og udstyr har været bedre stillet (i hvert fald før 1980ernes markante beskæring) end de fleste andre vesteuropæiske zoologiske museer; Naturhistorisk Museum i Arhus har bevidst investeret sin indsats $\mathrm{i}$ andre opgaver end opbygning, forvaltning og studium af globale systematiske samlinger.

Et andet strukturproblem i den internationale naturhistoriske museumsverden er, at kostbare faste forskerstillinger i en række tilfælde er blevet besat med biologer, hvis forskningsmæssige kvalifikationer og aktiviteter vedrører ikke-samlingsrelaterede emner, f. eks. inden for økologi. Problemet blev allerede i 1970erne påpeget $\mathrm{i}$ en forskningsrådsrapport om europæisk systematisk biologi ${ }^{3}$ og blev her skarpt paitalt som 'misuse of the scientific resource represented by the museum collections and facilities', men det eksisterer bestemt endnu, specielt måske i Mellemeuropa. Naturligvis er grænserne ikke altid simple at drage. Zoologisk Museum i København har f.eks. hidtil varetaget én videnskabelig aktivitet, som ikke er umiddelbart knyttet til samlingerne, nemlig den danske fugleringmærkning. Også i nogle af de lande, vi normalt sammenligner os med, ligger fugleringmærkningen på de nationale naturhistoriske museer, mens den $\mathrm{i}$ andre lande er knyttet til andre forskningsinstitutioner. Et vigtigt moment $\mathrm{i}$ en diskussion om, hvorvidt fugleringmærkning fortsat skal drives for museale midler bliver $\mathrm{da}$, om der blandt det givne lands biologiske institutioner findes nogen anden, der kan varetage denne aktivitet lige så godt. Og i vurderingen af et museums ressourceforbrug hertil må indgå en overvejelse af de 'indtægter', som en sådan udadrettet aktivitet skaffer museet i form af kontakter med, og opmærksomhed/goodwill fra den naturinteresserede offentlighed. Afgørelsen er, som sagt, ikke simpel.

\section{FORNYELSEN I DE \\ NATURHISTORISKE MUSEERS ARBEJDSFORMER}

Den systematiske biologis uløste opgaver har altså et gigantisk omfang, og den internationale naturhistoriske museumsverden har nogle strukturproblemer. 
52 Begge omstændigheder stiller krav om fornyelser i museernes arbejdsformer - fornyelser som i hvert fald nogle steder er i fuld gang.

Kurateringsprocedurerne ${ }^{4}$ rationaliseres, ikke mindst i kraft af moderne computerteknologi, som kan effektivisere arbejdet fra det indledende skridt med udskrivningen af det enkelte samlingseksemplars funddata-etikette til den afsluttende registrering af eksemplaret efter specialistens bestemmelse. På de store naturhistoriske museer har en detaljeret samlingsregistrering hidtil normalt været indskrænket til mindre afsnit (for zoologiens vedkommende typisk hvirveldyrsamlingerne), og en registrering af enkelt-individ-data fra større samlinger af hvirvelløse dyr vil efter mit skøn også i en overskuelig fremtid kun være en berettiget ressourceanvendelse i forbindelse med specifikke forskningsprojekter. Men det bør på alle museer være en høj prioritet at sikre materialets 'tilgængelighed' for det internationale forskersamfund: Først og fremmest ved at usorterede accessioner sorteres til de niveauer hvor specialister normalt arbejder (det er for hvirvelløse dyrs vedkommende typisk familie/underfamilie samt zoogeografisk region), og dernæst ved at registrere hovedtrekkene af samlingernes indhold, f.eks. at af familien X-idae omfatter det orientalske materiale 87 arter og $1100+$ ubestemte individer, det afrotropiske 22 arter og $550+$ ubestemte individer, herunder 160 fra Madagaskar. Sådanne oplysninger er værdifulde for specialisten, der under arbejdet med at skrive en monografi, eller lokal bestemmelseshåndbog, over familien $\mathrm{X}$-idae skal afgøre, om det er umagen værd at rette henvendelse til et givent museum om materialelån. Det er ønske- ligt - og formentlig realistisk - at oplysninger på dette niveau fra alle vigtigere museer inden for en overskuelig årrække skal kunne stilles til rådighed på en form, som er tilgængelig fra den enkelte forskers pc'er.

Med hensyn til fornyelserne i museumsstabenes forskningsprocedurer tegner der sig følgende mønstre:

1) Langt storre overvejelser ved valget af forskningsemne. Fordi der nu er så mange organismer, og så få systematikere til at studere dem, er det naturligt, at der melder sig et krav om en prioritering. Og højest prioritet må så gives til studiet af organismegrupper, hvis medlemmer af en eller anden grund må antages at være af bred interesse i det biologiske forskersamfund. Sådanne grunde kan være af mange slags, f. eks. en fylogenetisk nøgleposition eller påfaldende/usædvanlige adfærdsmønstre, fysiologiske egenskaber, relationer til andre organismer, udbredelsesmønstre og selvfølgelig direkte økonomisk/sundhedsmæssig betydning. Men modsat situationen for blot få årtier siden, vil man nu vanskeligt kunne retfærdiggøre artsniveausystematisk forskning $\mathrm{i}$ en given gruppe alene med, at gruppen 'er der, og ikke studeres af andre'. Selvfølgelig ligger der heri en fare for en ond cirkel, for grupper som der her og nu vides meget lidt om - og som man efter det netop anførte princip derfor skulle lade ligge - kunne jo illustrere forhold af stor generel interesse, som det så varer meget længe, før man får kendskab til. Bør princippet derfor ikke blive et absolut krav, bør det dog utvivlsomt følges så langt, at det enkelte museum kun investerer beskedne dele af sine forskningsressourcer i artsniveau-stu- 
dier af organismer, som ikke har 'kendt interesse'. Derimod forekommer det berettiget at stræbe efter, at tilvejebringe et nogenlunde detaljeret klassifikations-'skelet' på højere niveau for hele den levende verden; så har man et udgangspunkt for at drive kvalificeret artsniveau-systematik i tilfælde, hvor der findes forhold af særlig interesse.

2) Medmindre ganske sarlige forhold gør sig galdende, bearbejder man ikke langere enkeltstående indsamlinger eller museumsmaterialer, ligsom man ikke beskriver nye arter uden for omfattende revisioner af de grupper, de tilhører. Disse principper, som allerede i en årrække har været knæsat på flere af de forende museer, repræsenterer et markant brud med tidligere systematisk forskningspraksis, der meget ofte førte til afhandlinger som "The X-idae collected by the ..expedition to..", "The Y-idae in the collections of the ..Museum..» eller "Nine new species of Z-idae». Selvfølgelig betyder principperne, at tempoet $\mathrm{i}$ arbejdet med at få sat navn på alle de stadig ubeskrevne organismer nedsættes. Der beskrives nu markant færre nye arter pr 'systematiker-årsværk' end i århundredets start (hvilket dog også hænger sammen med, at der nu gennemgående undersøges/beskrives/illustreres betydelig flere detaljer på hver art). Til gengæld er de mere sammenfattende publikationstyper, der nu satses på, langt mere brugervenlige og har mere varig værdi end de førnæunte. $\mathrm{Og}$ et kardinalpunkt: de mindsker i høj grad risikoen for, at samme art beskrives flere gange under forskellige navne. Det er sket så tit, at det er en reel belastning for systematisk forskning: «Probably about 50 $\%$ of the time, and hence money, spent on a major taxonomic revision in entomology is needed to rectify factual errors by previous workers"s.

3) Mere vagt på gruppearbejde. Enkeltforfatter-publikationer har måske blandt museumsbaserede systematikere været fremherskende længere end blandt nogen anden kategori af naturvidenskabsfolk. Men også i denne disciplin ses behovet for gruppearbejde stadig tydeligere. Den enkelte systematiker kan således have frugtbart forskningssamarbejde

- med systematikere, som har speciale i samme organismegruppe, men som arbejder $\mathrm{i}$ andre dele af verden.

- med systematiker-kolleger, som er specialister i en anden organismegruppe, men hvis metodeekspertise supplerer hendes/hans egen. Moderne systematisk forskning betjener sig af et bredt spektrum af krævende metoder, og det er ikke muligt (i hvert fald ikke rationelt) for hver enkelt medarbejder på en given museumsafdeling at holde sig helt à jour med alt.

- med ikke-systematikere, som er interesserede i samme gruppe. Der kommer i disse år megen god forskning og gensidig inspiration ud af, at adfærdsbiologer, populationsbiologer, ultrastrukturforskere, molekylærbiologer m.fl. etablerer projektsamarbejde med systematikere på en museumsafdeling. For som sagt er det den fylogenetiske systematik, der făr al biologisk information til at falde på plads i sammenhængende historier (fig.3).

4) Mere (lokal og international) ledelsesstyring af den museale forskning.

Forskningsfrihed sættes højt af alle, men en stigende grad af ledelses-styring vil være uundgåelig, hvis en række af den systematiske biologis mest ressourcekrævende opgaver skal løses. For eksempel vil tilvejebringelsen af det brugbare og nogenlunde 
NIELS P. KRISTENSEN

Fig. 3: Efterkrigstidens udvikling af det teoretiske og metodiske apparat til rekonstruktion of nulevende organismers fylogenetiske slagtskabsforhold har betydet vesentlige landvindinger for den systematiske biologi. Den ser også ud til at medfore en stigende interesse for systematikkens resultater hos andre biologer, som fär bedre mulighed for at forstå deres resultater vedrorende f.eks. okologiske, fysiologiske og adfardsmessige forhold i et evolutionert perspektiv. I såkaldt 'bistorisk okologi' analyseres således udviklingen af forskjellige okologiske trak hos en organismegruppe, idet de projiceres pa et 'stamtra' for gruppens medlemmer.

Her illustreres som et fint stykke moderne museumszoologi den diskussion af skojtelobertegers tilknytning til det marine miljo, som blev affodt af den nylige opdagelse af en hidtil ukendt udviklingslinie blandt saidanne tager $i$ det nordostlige Australien (et falles dansklaustralsk

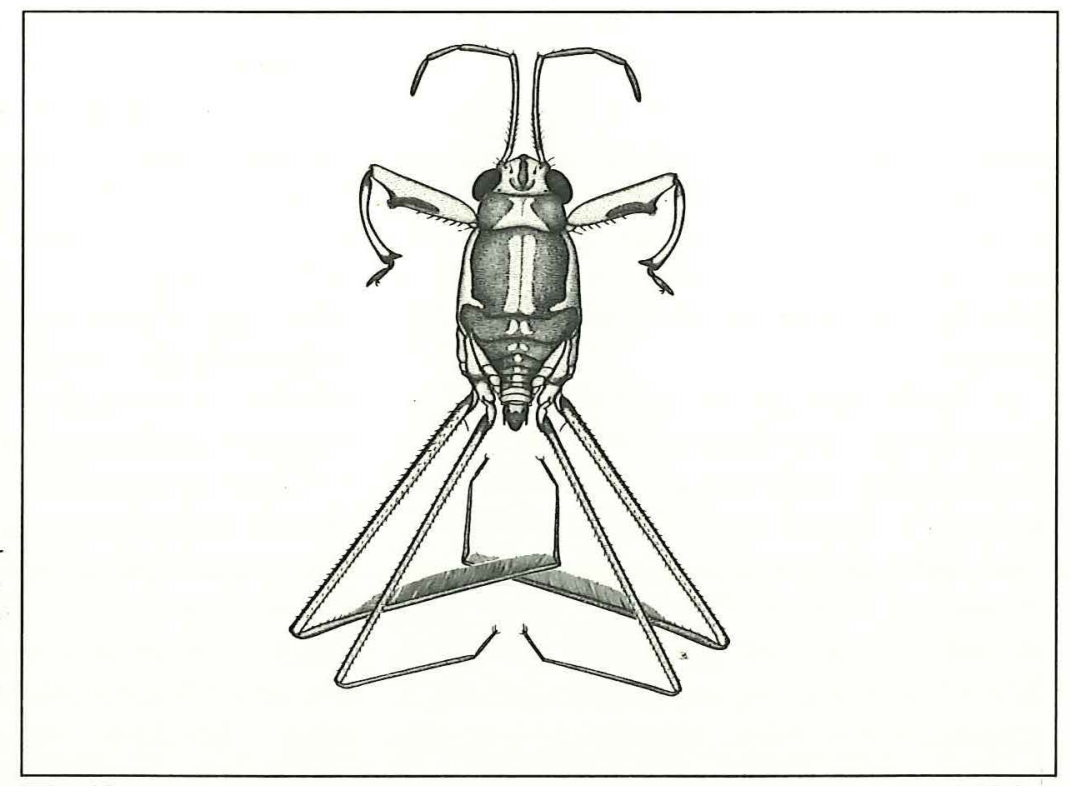
projekt). Den nyopdagede Austrobates rivularis Andersen of Weir, 1994 (foroven) er ligesom gruppens tidligst differentierede former, Metrocorini og fjernere slagtninge, limnisk (knyttet til ferskvand), mens dens narmeste slagtninge, medlemmerne af slagten Halobates, er marine; det samme gjalder medlemmerne af Asclepios, som er de narmeste slagtninge til den udviklingslinie, der gav ophav til både Austrobates og Halobates. - Stamtraerne forneden viser de mulige scenarier for udviklingen af denne situation: (A) Aclepios og Halobates er uafhangigt af binanden gået fra det limniske miljo til det marine; (B) skiftet fra limnisk til marint miljo skete allerede $i$ den falles stamlinie for Asclepios + Halobates + Austrobates, og sidstnavnte er så sekundart gået tilbage til fersvand; (C) fra en rent limnisk stamform udviklede den felles stamlinie for Asclepios + Halobates + Austrobates tolerans for både salt- og ferskvand og 'indtog' tillige mangrove- og estuarie-habitater: hver af de nulevende slagter realiserer kun en del af stamliniens potentiale. Forfatterne giver grunde til at foretrakke model $C$. 
detaljerede klassifikations-'skelet' for en meget stor insektfamilie (måske med et femcifret antal beskrevne arter) være et forehavende, som ingen forsker kan håndtere som enkeltperson. Skal man i sådanne tilfælde komme videre, kræves der en beslutning på ledelsesplan på et større museum - eller ideelt på flere samarbejdende museer forskellige steder i verden om, at nu vil man altså søge at realisere dette mål inden for en overskuelig tidshorisont og dertil afsætte A seniorforskere, B postdocs, X PhD stipendier, Y teknikere og Z driftsmidler.

Internationalt samarbejde vil også være en forudsætning for at tilvejebringe den samlede oversigt over alle navngivne organismer, som vi mangler i dag. Råmaterialet findes $\mathrm{i}$ vid udstrækning allerede på de største museer - i form af kartoteker opbygget af flere forskergenerationer - men den samlede oversigt vil kræve massiv ressourceinvestering $i$ at overføre denne information til elektroniske databaser; igen opgaver af en størrelsesorden, der kræver beslutninger på ledelsesplan. Fra den basale katalogisering er det logisk at tænke videre i retning af $\mathrm{f}$. eks. en omfattende cd-rom dokumentation ${ }^{5}$ af de kendte organismer, ikke mindst fordi det er svært at forestille sig, at forskere på 'yng$\mathrm{re}^{\prime}$ institutioner (specielt i tredieverdenslande), nogensinde skulle få rimelig adgang til de biblioteksfaciliteter, som i dag er en forudsætning for kvalificeret systematisk forskning. Koordinering af sådanne aktiviteter vil utvivlsomt være blandt de naturhistoriske museumslederes vigtigste opgaver $\mathrm{i}$ det 21 . århundrede.

Endelig må man forestille sig et fremtidigt nationalt og internationalt naturhistorisk museumssamarbejde på ledelsesplan om emner som i dag kan forekomme kontroversielle. Vigtigst forekommer overførsler af samlingsafsnit - og stillinger! - imellem museer (eventuelt som langfristede lån, hvis ordningerne på denne måde kan gøres mere 'spiselige' for afgiverparterne), så man i højere grad end nu får koncentreret kræfterne og får opbygget 'centres of excellence' for studiet af forskellige organismegrupper. Også udformning af strengere krav til nybeskrivelser og til anbringelse af primære typer og andet unikt materiale kan komme på tale. Hvor længe endnu kan det systematiske forskersamfund $\mathrm{f}$. eks. leve med, at en treliniers nybeskrivelse af en art i et hvilketsomhelst non-refereed tidsskrift og på (for zoologiens vedkommende) et hvilketsomhelst sprog principielt har nomenklatorisk gyldighed? Og med at nye arter kan beskrives på grundlag af materiale som opbevares i private samlinger?

Forskere er generelt individualister, og godt det samme. Men forskerne tilknyttet verdens vigtigere naturvidenskabelige samlinger kan blive nødt til i højere grad at danne fælles front og til at koordinere indsatsen bedre end nu, hvis vores forskningsfelt skal få den gennemslagskraft, det fortjener.

\section{SUMMARY}

Natural bistory collections and research

Among the research activities linked to natural history collections, biological systematics stands out for the topicality conferred upon it by growing concern over the biodiversity crisis. Systematic biologists, most of whom work in natural history museums, are faced with the task of naming and describing/redescribing millions of undescribed or poorly described organisms from rapidly dwindling 
56 natural habitats, and of classifying the known organisms according to their phylogenetic affinities, so that all kinds of biological information on all kinds of organisms may be pieced together into coherent patterns. In view of the enormity of these tasks, systematists are now rightly demanding a greater share of the resources currently spent on biological research. But the question then naturally arises whether resources already available are being put to optimal use; it seems evident that this is not the case.

The major structural problem in the community of natural history museums is arguably that resources are too thinly spread: Too many museums do not have the staff and the equipment needed to cope efficiently with the research collections under their care. Another structural problem is that in some countries too many museum positions have been given to biologists lacking a background in systematics or other collection-based research.

The performance of museum-based systematic biology can be enhanced through ongoing and foreseeable shifts in a number of working procedures. In curation, high priority should be given to the sorting of unsorted accessions (to 'loanable entiti$e^{\prime}$ ) and to making databases outlining collection holdings available to the international community of systematists. As far as research is concerned, changing standards include: 1) Adoption of more strict priority criteria for selecting taxa for study. 2) Abandonment of the practice of working up the holdings of a single museum, or the material obtained from a single expedition, as well as the description of new taxa outside the context of comprehensive revisions. 3) More emphasis on research projects in which several scientists with different backgrounds/skills join forces. 4) Decisions taken at the managerial level, often involving museums from several countries, playing an increasingly important role in shaping future scientific activities centred on natural history collections.
Niels P. Kristensen er mag. scient. $i$ entomologi og siden 1968 ansat ved Entomologisk Afdeling på Zoologisk Museum, Kobenhavns Universitet; $d r$. scient. 1984; 1986-89 museets bestyrer og formand for Konsistoriums Permanente Museumsudvalg; docent 1990.

Adr: Zoologisk Museum, Universitetsparken 15, DK2100 Kobenhavn Ø.

\section{NOTER OG LITTERATUR}

* Basert på et indlæg ved Museumshøjskolens museologiske forelæsninger på Nationalmuseet 3/3/1994: 'Museumssamlinger og naturvidenskab'.

1. Hammond, P.M. 1992. Species inventory. Pp. 17-39 i B. Groombridge (ed.) Global Biodiversity, Status of the Earth's Living Resources. Chapman \& Hall.

2. Se f.eks. Gaston, K.J. \& May, R. M. 1992. Taxonomy of taxonomists. Nature 356: 281-282.

3. Taxonomy in Europe. ESRC Review No 13. European Science Foundation, Strasbourg, 1977.

4. 'Kuratering' findes ikke i den seneste udgave af Gyldendals fremmedordbog, men denne fordanskning af det engelske 'curation' er efterhånden blevet daglig sprogbrug for summen af aktiviteter vedrørende forvaltningen af videnskabelige samlinger.

5. Mound, L. A. \& Gaston, K. J. 1993.

Conservation and systematics - the agony and the ecstasy. I Gaston, K. J., New, T. R. \& Samways, M. (eds) Perspectives on Insect Conservation. Intercept. 